\title{
Measuring Efficiency of Fuel Oil Usage in PT PLN: A Short-Run Analysis
}

\author{
Tongam Sihol Nababan \\ Department of Development Economics \\ Faculty of Economics, Nommensen HKBP University \\ Medan, Indonesia \\ tsnababan@gmail.com
}

\begin{abstract}
This study aims to measure and to analyze the efficiency level of fuel oil usage in units of PT. PLN generation. The study result shows that until now the PLN is still operating in inefficiency condition, because of foil oil usage. The energy consumption level of fuel oil is less efficient compared with coal energy in generating electricity. Based on the short-term CobbDouglass analysis, the average decrease in oil fuel usage efficiency over the period 2011 - 2015 is $17.21 \%$ per year. Allegedly, even though the portion has decreaseddue to the unsustainable supply of non-fuel fuel, it is important to maintain the use of fuel oil.The government is asked to continue evaluate the use of fuel oil inputs, diversify input energy and increase efficiency in producing electricity in Indonesia.
\end{abstract}

Keywords : efficiency, electrical energy, input, fuel oil, PT. PLN.

\section{INTRODUCTION}

Electrical energy has become a fundamental requirement of modern society. The level of electricity consumption can be an indicator in determining the prosperity. The need for electricity continues to increase along with the growth of population and economic growth rate. According to the Central Bureau of Statistics, Indonesia's population amount to approximately 231 million people in the year of 2010 and will become 293 million by the year of 2035 . The population growth with an average range of $0.89 \%$ to $1.24 \%$ influences the use of various resources such as land for settlement, agriculture, industry, and others. Of course, this situation will increase energy consumption, including electricity[1]. Besides, according to Khayati [2] the improvement of the quality of life, will tend to increase electricity consumption in daily activities. PT PLN (State Owned Electrical Company), as a government institution must provide electric power in Indonesia, and continue to develop its business in serving the needs of the people of Indonesia.
To support the provision of electricity in Indonesia, PT. PLN has built various power plants throughout Indonesia, ranging from hydroelectric power plants, steam, gas, gas other fuels. The existing power plant currently mostly uses coal as its fuel [3]. Soebagio [4] stated that fossil energy is the most energy used as a power plant because fossil energy is the easiest to be convinced, reliable and economical.

Noting that fuel is a vital component, the government has issued a national policy of "fuel mix" (energy mix) where consumption of oil will continue to shrink its portion, replaced by other more sustainable fuels, especially new and renewable energy [5]. In 2025 the portion of oil fuel can be reduced to only 5\%. PT PLN has tried to accelerate energy diversification, efficiency improvement and optimization of the power supply of non-oil fuel generating units.

Though the consumption of fuel oil has declined and less efficient than other inputs, almost 95\% of PT PLN units still use fuel oil combined with coal and natural gas in power generation. Due to the unbalanced supply of non-fuel oil and even though the portion has decreased, it is important to maintain the use of fuel oil. The efforts to provide electricity by using fuel oil are capital-intensive, and the obstacle is the financing factor. Similarly, the higher world oil prices also exacerbate PT PLN's financial condition as most PLN's power plants still depend on fuel oil. Therefore, the use of fuel oil should pay attention to the level of efficiency. Theoretically, Farrel [6] distinguished it into three parts, namely: technical efficiency, cost efficiency (allocative), and overall efficiency (economic).

Based on the above phenomena, the understanding of the efficiency level of PT PLN is still an interesting thing to be studied, especially in the use of fuel oil as one of the input factors in producing electrical energy. Therefore, this study aims to analyze the level of efficiency and elasticity of fuel oil consumption in units of PT PLN generation region. However, this study only focuses on the use of fuel oil to produce electrical energy. Furthermore, this study also reviews the elasticity, whether the fuel oil usage by PT PLN is in the position of increasing, decreasing, or return to scale. 
The results of the study are expected to be inputs to support government policy in evaluating the use of fuel oil input, diversification of input energy, and increasing efficiency in producing electricity in Indonesia.

\section{LITERATURE REVIEW}

Siahaan [7] expresses that efficiency is often a concern in the production process. It is one of the parameters used to measure the firm performance. Coelli et al. [8] and Tribuana [9] revealed that the concept of efficiency comprises technical, allocative, and overall efficiency.

According to Gaspersz [10] the measurement of efficiency index can be explained using the basic concept of production theory. In a company, production is a process of transforming added value from input to output. A standard function called "production function," expresses the relationship between the input used and the resulting output. The most widely used production function is the CobbDouglas production function which takes the form of linear-logarithmic. The information that can be obtained directly from the production function is efficiency index and elasticity index.

Measuring efficiency does not have to use the production function. The other ones are the cost function and profit function which can measure the efficiency. The choice between these models is usually performed by exogenous assumptions. When the input acts as exogenous variables, the production function is the right choice. Otherwise, Hossain et al. [11] and Jono [12] stated that when output acts as an exogenous, the cost function is the right function to use.

The Cobb-Douglas function is a function of power consisting of two or more variables, where one variable is called a variable of $\mathrm{Y}$ (independent variable), and the other is a variable of $X$ (independent variable). The settlement of the relationship between $\mathrm{Y}$ and $\mathrm{X}$ is usually estimated by regression where the variation of $X$ will influence the variation of $\mathrm{Y}$. The productivity measurement model based on the Cobb-Douglas production function approach is one of the most widely used in productivity analysis The Cobb-Douglas production function includes an exponential form involving two/more independent variables (X) with one independent variable (Y). Cobb-Douglas model is also a nonlinear regression equation. The formulation of Cobb-Douglas is:

$Q=\alpha L^{\beta 1} K^{\beta 2} F^{\beta 3} e^{\mu}$

Where $\mathrm{Q}=$ output, $\mathrm{L}=$ labor input, $\mathrm{K}=$ capital input, $\mathrm{F}=$ fuel input, $\alpha=$ intercept or efficiency parameter, $\beta=$ elasticity, $\mu=$ error term. The linear logarithmic form of the above function is:

Ln $Q=\alpha+\beta 1 \operatorname{Ln} L+\beta 2 \operatorname{Ln} K+\beta 3 \operatorname{LnF}+\mu$
In the production process, efficiency refers to the ratio between the output produced with the number of inputs required which can be mathematically specified as follows:

$$
\begin{aligned}
\text { Efficiency } & =\text { Output / Input } \\
& =\mathrm{Q} /\left[\mathrm{L}^{\beta 1} \mathrm{~K}^{\beta 2} \mathrm{~F}^{\beta 3}\right] \\
& =\alpha \cdot \mathrm{e}^{\mu}
\end{aligned}
$$

Or in logarithmic form: $\operatorname{Ln} \alpha+\mu$

Thus, the efficiency parameter $(\alpha)$ can be obtained directly from the Cobb-Douglas production function.

Many studies have chosen the CobbDouglas function because of the simplicity of the model and give the satisfactory results. The studies were performed by Marlina et al. [13], Ikram et al.[14], Firmawan [15], Taylor et al. [16], and Rahmani [17]. On the other hand, some publications have chosen a form of translog which not impose restrictions. However, the estimated translog function will require more degrees of freedom, so it is often not statistically adequate for limited data periods and observations of its research.

\section{RESEARCH METHOD}

To describe the data associated with the use of fuel oil inputs in the production of electrical energy and to obtain an overview of the efficiency, descriptive analysis is applied.

Considering the simplicity of the approach, the limitation of data, and the short study period, and so to analyze the use of fuel oil by PT PLN from the year of 2011 to 2015, this study uses the short-term Cobb-Douglas production function, which assumes that other input factors are considered fixed, and there is only one variable input that is fuel oil. Thus the short-term Cobb-Douglas production function is specified as follows:

$Q=\alpha F U E L^{\beta}$

Then transformed into logarithmic form:

$$
\operatorname{Ln} Q=\operatorname{Ln} \alpha+\beta L n F U E L+u
$$

Where $\mathrm{Q}=$ total electricity production of PT PLN units/Province $(\mathrm{GWh})$, FUEL = fuel oil input to produce electrical energy (kilo liters), $\alpha$ is a constant/intercept which is an efficiency index. The greater the value of $\alpha$ means the higher fuel consumption efficiency, $\beta$ is the output elasticity of FUEL with scale: if $\beta=1$, production is a constant return to scale, if $\beta<1$ production is decreasing return to scale, if $\beta>1$ production is an increasing return to scale. 


\section{DISCUSSION}

Whether the efficiency of fuel oil usage has declined or increased, it is necessary to analyze by using the Cobb-Douglas production function. The short-term Cobb Douglas production function can take the form of transformation or original form. Table 1 presents the result. For production analysis, Cobb Douglass production function uses the original form. The result of analysis has met the two assumptions.

TABLE 1. SHORT-RUN COBB-DOUGLAS PRODUCTION FUNCTION

\begin{tabular}{|c|c|c|c|}
\hline Year & $\begin{array}{l}\text { Transformation } \\
\text { Form }\end{array}$ & $\begin{array}{c}\text { Original Form }(Q= \\
\left.\alpha F U E L^{\beta}\right)\end{array}$ & $\begin{array}{c}\text { Efficiency } \\
\text { Ratio }\end{array}$ \\
\hline 2011 & $\begin{array}{c}\operatorname{Ln} Q=-5.8236+ \\
1.0168 \text { LnFUEL }\end{array}$ & $\begin{array}{c}Q= \\
0.0030(\text { FUEL })^{1.0168}\end{array}$ & - \\
\hline 2012 & $\begin{array}{c}\operatorname{Ln} Q=-5.8442+ \\
1.0177 \operatorname{LnFUEL}\end{array}$ & $\begin{array}{c}Q= \\
0.0029(\text { FUEL })^{1.0177}\end{array}$ & $\begin{array}{c}\text { Decreaseof } \\
0.033 \% \text {. }\end{array}$ \\
\hline 2013 & $\begin{array}{c}\operatorname{Ln} Q=-5.5840+ \\
0.9972 \operatorname{LnFUEL}\end{array}$ & $\begin{array}{c}Q= \\
0.0038(\text { FUEL })^{0.9972}\end{array}$ & $\begin{array}{c}\text { Increaseof } \\
31,03 \% \text {. }\end{array}$ \\
\hline 2014 & $\begin{array}{c}\text { LnQ } Q=-5.8191+ \\
1.0145 \text { LnFUEL }\end{array}$ & $\begin{array}{c}Q= \\
0.0030(F U E L)^{1.0145}\end{array}$ & $\begin{array}{c}\text { Decrease of } \\
21,05 \% \text {. }\end{array}$ \\
\hline 2015 & $\begin{array}{c}\text { LnQ } Q=-9.0704+ \\
1.3834 \text { LnFUEL }\end{array}$ & $\begin{array}{c}Q= \\
0.000115(\text { FUEL })^{1.3834}\end{array}$ & $\begin{array}{c}\text { Decrease of } \\
96,02 \% \text {. }\end{array}$ \\
\hline
\end{tabular}

Analysis of the efficiency of the use of fuel oil input are as follows:

(1) The efficiency index of short-term PT PLN's production in 2011 is the coefficient of intercept as 0.0030 while in 2012 is 0.0029 . It means that PLN's production efficiency in 2012 compared to the 2011 production efficiency is 0.0029 / $0.0030=0.967$. It appears that PLN production in 2012 when compared to production efficiency in 2011, decreased by $0.033 \%$. Briefly, efficiency of PLN in 2012 is lower than in 2011 for the use of the same variable input.

(2) The efficiency index of short term PT PLN's production in 2012 is the coefficient of intercept as 0.0029 while in 2013 is 0.0038 . It means that PLN's production efficiency in 2013 compared to 2012 is $0.0038 / 0.0029=1.3103$. It appears that PLN's production efficiency in 2013 when compared to production efficiency in 2012, increased by $31.03 \%$. Briefly, PLN's production process in 2013 is higher than in 2012 for the use of the same variable input.

(3) The efficiency index om PT PLN's production in 2013 is the coefficient of intercept as 0.0038 while in 2014 is 0.0030 . It means that PLN's production efficiency in 2014 compared to 2013 production efficiency is $0.0030 / 0.0038=$ 0.7895. It appears that PLN's production efficiency in 2014 when compared with production efficiency in 2013, decreased by $21.05 \%$. Briefly, PLN's production process in 2014 is lower than in 2013 for use for the same variable input.

(4) The efficiency index of short-term PT PLN's production in 2014 is the coefficient of intercept as 0.0030 while the efficiency index in 2015 is 0.000115 . It means that PLN's production efficiency in 2015 compared to production efficiency in 2014 is $0.000115 / 0.0030=0.038$. It appears that PLN production

efficiency in 2015 when compared to production efficiency in 2014, decreased by $96.20 \%$. Briefly, PLN production process in 2015 is lower than in 2014 for use for the same variable input.

Considering the efficiency ratios in the period of 2011 to 2015, it can be stated that there has been a decrease in efficiency for the use of fuel oil by PT PLN averaging $17.21 \%$ per annum. Then, the production elasticity of the fuel oil used by PLN (shown by the coefficient of $\beta$ ) in the period of 2011 to 2015 is $1.0168 ; 1.0177 ; 0.9972 ; 1.0145 ; 1.3834$ respectively. On average, during the period, the production elasticity of fuel oil is $1.08592(\beta>1)$, and production is still on the stage of increasing return to scale. That is, the addition of the use of fuel oil by PLN can increase the average productivity of fuel oil. But in the efficiency ratio, the use of fuel oil during the period of 2011 - 2015 tends to decrease the efficiency.

Given that the use of fuel oil tends to be inefficient, its use should be reduced and replaced by the other more efficient energy. However, the efforts to reduce the fuel oil consumption for electricity production are facing various obstacles and challenge both technical and economic. Firstly, to increase the electrification ratio, PT PLN will build new plants (diesel power plants) in remote and isolated areas. The increased capacity and production of the diesel power plant will increase fuel oil consumption in the electricity sector. Secondly, until now the existence of diesel power plant is still very strategic considering several advantages that are high load fluctuation capability, fast start-up, practical size, installation, easy to move, fuel supply is relatively easy, varied power capacity (10KW to $18 \mathrm{MW})$. This condition makes the diesel power plant as a "distributed generation" or to be a reliable small-scale generator although it has high production costs.

Third, in general, the selection of generating sites is attempted to fulfill the principle of regional balance, that is, the electricity needs of a region are filled mostly by the power station located in the area and are not much dependent on the transfer from others through distribution channels or interconnection transmission. Thus, the availability of primary energy in the area for non-fuel power plants is needed. In fact, non-fuel energy sources such as hydro-power, gas, coal, geothermal and so on are not always available at power plants or load centers. Fourth, compared to the relatively dispersed supply chain of fuel, reliable and accessible, the coal and gas are more risky. The limited number and distribution of consumers make the continuity of supply to be very potential to face obstacles. Similarly, constraints on the continuity of gas supply 
are likely to be "small," but they have "very significant" risks as similar to coal supply constraints.

Therefore, to reduce fuel oil consumption significantly in the electricity sector in Indonesia, gas has the potential to replace fuel oil by considering its more abundant availability compared to fuel oil and its economic aspect. On a relatively large system, when the steam power plant can fulfill the base load, the gas generator can replace the fuel oil generator role at the peak load. Then, to anticipate the scarcity and increasingly expensive of fuel oil and reduce import dependence, the development of alternative fuel for diesel become a strategic one, for example, development of alternative fuel for diesel. Furthermore, by relying on the development and utilization of new and renewable energy technologies can replace the diesel power plant functions in all modes of operation through the development of hybrid systems. Development of electricity in isolated electrical systems and on small islands, the use of oil-fueled generators is still an option. However, to reduce fuel oil consumption, the diesel power plant needs to be combined with other small-scale nonfuel oil power plants or hybrid.

\section{CONCLUSION}

In the national electricity system, the use of fuel oil holds the largest expenditure portion with an average of $70 \%$ of the total operational cost. However, the level of energy consumption of fuel oil is less efficient than coal energy in generating electricity per KWh. On average, 1 liter of fuel is only able to produce $0.27 \mathrm{kWh}$ of electricity, while $1 \mathrm{~kg}$ of coal produces $0.53 \mathrm{kWh}$ of electrical energy. Considering the efficiency ratios in the period of 2011 - 2015, it can be stated that there has been a decrease in the use of fuel efficiency by PLN averaging $17.21 \%$ per annum.

Efforts to reduce fuel oil consumption for the electricity sector is one of the national strategic issues. In practice, however, efforts to decrease fuel oil consumption are facing various obstacles and challenges, namely; the low electrification ratio, the limitations of alternative diesel replacement technology, the limited availability of local primary energy and the unreliable supply of non-fuel. To reduce the consumption of fuel oil, it is necessary to recommend that gasification of fuel plant and renewable energy can be more activated. Gasification scenario can be done through optimization of the gas generator to replace diesel power plant, especially during the peak load.

\section{References}

[1] D. Rohi, J. E. Luik, "Kesadaran Masyarakat Surabaya untuk Memiliki Gaya Hidup Ramah Lingkungan "Green Living” Melalui Menghemat Penggunaan Energi Listrik", 1-14,
2011. URL: petra.ac.id/16377/1/Publikasi1 repository _97030_905.pdf)

[2] N. Khayati, "Analisis Efisiensi Relatif Wilayah Usaha Penyediaan Tenaga Listrik PT PLN (Persero) Tahun 2002 - 2008", Tesis, Fakultas Ekonomi, Program Magister Perencanaan Dan Kebijakan Publik, Universitas Indonesia, Jakarta, 2010. URL: lib.ui.ac.id/file?file = digital/131325...Analisis $\% 20$ efisiensi-HA.pdf

[3] PT. PLN, "PLN Statistics 2015", Corporate SecretaryPT PLN (Persero), Jakarta, 2015. URL: www.pln.co.id/.

[4] A. Soebagio, "Politik Energi : Penyediaan Energi Nasional secara Berkelanjutan dalam Menyikapi Perubahan Iklim”, Seminar Nasional Lingkungan Hidup, Universitas Kristen Petra, $\quad$ Surabaya, $29 \quad$ Mei 2010. URL:https://atmonobudi.wordpress.com/public ations-2\%.

[5] Z. Arifin, Konsumsi BBM Untuk Pembangkit Listrik Di Indonesia; Kecenderungan, Permasalahan Dan Solusinya. "Mineral \& Energi", Vol. 13, No. 2, 85-95, Juni 2015. URL: http://www.litbang.esdm.go.id/images/stories majalah_juni_2015/10.pdf

[6] M. J. Farrell, The Measurement of Productive Efficiency. “Journal of Royal Statistical Society", Vol. 120, No. 3, 253 - 290, 1957. URL: https://www.aae.wisc.edu/aae741/Ref/Farrell\%201957.pdf

[7] O. P. Siahaan, "Efisiensi Teknik Unit Usaha BUMN: Analisa Data Panel Usaha Industri Indonesia, 1981 1991". Disertasi. Fakultas Ekonomi Universitas Indonesia. Jakarta, 2000

[8] T. J. Coelli, D. S. P. Rao, C. J. O’Donnell, G. E. Battese, An Introduction to Efficiency and Productivity Analysisi, $2^{\text {nd }}$ Edition, Springer Science + Business Media, Inc., New York, 2005 URL: http://facweb.knowlton.ohiostate.edu/pviton/co urses/crp394/coelli_Intro effic.pdf

[9] N. Tribuana, "Pengukuran Indeks Efisiensi Teknik Usaha Penyediaan Tenaga Listrik Sebelum dan Sesudah Perubahan Status Hukum Menjadi Persero". Thesis. Magister Perencanaan dan Kebijakan Publik, Fakultas Ekonomi, Universitas Indonesia, 2005. URL: perpustakaan.bappenas.go.id/lontar/file?file= digital/159283...-

[10] V. Gaspersz, Ekonomi Manajerial (Managerial Economics), Landasan Analisis dan Strategi Bisnis Untuk Manajemen Perusahaan dan Industri. PT. Percetakan Penebar Swadaya, Jakarta, 2011

[11] M. Z. Hossain, M. I. Bhatti, M. Z. Ali, An Econometric Analysis Of Some Major Manufacturing Industries: A case study. "Managerial Auditing Journal", Vol. 19 No. 6, 790795, $2004 . \quad$ URL: https://www.researchgate.net/publication/241708167.

[12] Jono.Analisis Produktivitas Pabrik Spiritus Menggunakan Fungsi Produksi Cobb-Douglas (Studi Kasus Di PT. XYZ Yogyakarta), "Spektrum Industri", Vol. 14, No. 2, $109-$ 230, $2016 . \quad$ URL: journal.uad.ac.id/index.php/Spektrum/article/d ownload/.../2710

[13] Marlina, E. Sribudiani, Sudarmalik. "Efficiency Of Steam Production Analysis At Pulp And Paper Industry" Department of Forestry, Faculty of Agriculture, University of Riau, 2013 URL:https://jom.unri.ac.id/index.php/JOMFAPERTA/artic le/viewFile/2669/2601

[14] M. A. M. Ikram, A. Prasmuko, D. F. Anugerah, I. N. Kurniati, Analisa Tingkat Efisiensi Sektoral dan Respon Kebijakan Ekonomi Sektoral di Daerah, (2012). "Buletin Ekonomi Moneterdan Perbankan", Volume 14, Nomor 3, 317-338, Januari 2012. URL: http://www.bi.go.id/id/publikasi/jurnal.

[15] M. F. Firmawan, “Analisis Nilai Tambah, Efisiensi Dan FaktorfaktorYang Mempengaruhi Output IndustriMinyak Goreng Sawit Di Indonesia”, Tesis, Departemen Ilmu 
Ekonomi Fakultas Ekonomi Dan Manajemen, Institut Pertanian $\quad$ Bogor, 2009.. https://id.123dok.com/document/download/6q mplnwq

[16] P. Taylor, O. I. Tigue, N. Trudeau, M. Francoeur, "Energy Efficiency Indicators For Public Electricity Production From Fossil Fuels", IEA Information Paper, International Energy Agency (IEA), 5-23, 2008. URL:https://www.iea.org/publications/freepubli cations/publication/En_Efficiency_Indicators.p df

[17] S. Y. Rahmani, "Analisis Efisiensi Pada BUMN Privatisasi di Indonesia Dengan Pendekatan Fungsi Produksi CobbDouglass", Tesis, Sekolah Pascasarjana Universitas Sumatra Utara (USU), 2008 URL: http://repository.usu.ac.id/bitstream/handle/12 3456789/7205/08E00753.pdf? sequence $=1$ \&is Allowed=y 